Check for updates

The BMJ

Cite this as: $B M J 2020 ; 370: m 3400$ http://dx.doi.org/10.1136/bmj.m3400 Published: 02 September 2020

\section{Covid-19: US FDA fires spokesperson over misleading claims about convalescent plasma}

\section{Elisabeth Mahase}

The US Food and Drug Administration has reportedly fired its chief spokesperson, Emily Miller, after just 12 days in the job, after criticism of the agency for misleading claims about the benefits of convalescent plasma in treating covid-19.

On 23 August the FDA approved convalescent plasma for emergency use in hospital patients with covid-19. At the time, President Donald Trump, the FDA commissioner Stephen Hahn, and the health and human services secretary Alex Azar all claimed that plasma reduced deaths by 35\%, sparking criticism from experts who warned that there was not enough evidence to show that convalescent plasma worked.

The 35\% figure was not included in the FDA's authorisation letter, the memo written by FDA scientists, or the often cited Mayo Clinic study looking at the effect of plasma on mortality among patients admitted to hospital with covid-19.

Miller-formerly a journalist and the communications director and spokesperson for the Republican Senator Ted Cruz's re-election campaign-has since been fired by the FDA, and the Department of Health and Human Services has terminated the contract of one of its public relations consultants. The New York Times said that the consultant had advised Hahn to correct the misleading $35 \%$ claim. $^{2}$

\section{Insufficient evidence}

A preprint of a paper, ${ }^{3}$ which has been submitted to BMJ Open but not yet peer reviewed, has looked at the currently available literature on convalescent plasma for severe covid-19 illness. Researchers from the UK Drug Safety Research Unit and the University of Portsmouth used the Benefit-Risk Action Team framework to assess the treatment when compared with standard care, placebo, or other treatments. They included four studies with comparative data.

The team found that one study, a randomised controlled trial, reported a "non-statistically significant shortening of time to clinical improvement of 2.15 days ( $95 \%$ confidence interval -5.28 to 0.99 days) in the intervention group compared with the control group, with a possible signal of increased efficacy amongst a small subset of patients with severe but not life threatening disease.”

However, they noted that this study may have been underpowered and that the findings of the other three studies-controlled non-randomised studies-were "limited by small patient numbers, lack of randomisation, and confounding by co-administration of other treatments."

The team concluded that there was "insufficient evidence" and that they were unable to complete the data summary table for a systematic benefit-risk assessment. "As such a benefit-risk conclusion could not be made," they wrote.

Mahase E. Covid-19: US approves emergency use of convalescent plasma despite warnings over lack of evidence. BMJ2020;370:m3327. doi: 10.1136/bmj.m3327 pmid: 32843328

2 Kaplan S, Thomas K. Two PR experts at FDA have been ousted after blood plasma fiasco. New York Times 2020 Aug 28. https://www.nytimes.com/2020/08/28/health/blood-plasma-fda.html.

3 Davies M, Lane S, Evans A, et al. Convalescent plasma in treatment of covid-19: a review of evidence for a living systematic benefit-risk assessment. medRxiv 2020 Aug 26. https://www.medrxiv.org/content/10.1101/2020.08.24.20180729v1.

This article is made freely available for use in accordance with BMJ's website terms and conditions for the duration of the covid-19 pandemic or until otherwise determined by BMJ. You may use, download and print the article for any lawful, non-commercial purpose (including text and data mining) provided that all copyright notices and trade marks are retained. 